\title{
都市と農村の共生を視点とした 優良田園住宅制度の活用方策
}

\section{A CASE STUDY ON USING RURAL RESIDENTIAL INSTITUTION FROM VIEWPOINT OF SYMBIOSIS WITH CITY AND RURAL AREA}

\section{千石達也 - $* 1$ 松岡佳秀 - $* 2$ \\ 瀬戸口㓮—*3 小林英嗣— $* 4$}

キーワード

都市郊外部，地方都市，優良田園住宅，田園居住

Keywords :

Urban fringe area, Local cities, Rural residence, Rural living

\author{
Tatsuya SENGOKU ——* $* 1$ \\ Tsuyoshi SETOGUCHI —*3
}

Yoshihide MATSUOKA — $* 2$ Hidetsugu KOBAYASHI $-* 4$

The purpose of this paper is to consider the image of residential environment in urban fringe area of local cities. We analyzed some examples, which used rural residential institution in five municipalities in Hokkaido. As a result of analysis, we pointed out four investigation items : rural residence, agriculture environment, farm village community, and land use of whole urban fringe area. These four items are important for planning of suburban environment.
1.はじめに

近年、環境問題や自然保護問題が様々な場所で取り上げられ、我 々の生活に関わる身近な問題として認識されるようになり、農村を 含めた自然的な環境を計画的に維持、保全することが地域において 大きなテーマになりつつある。

また、今日の農業情勢の悪化により農村では過瑓化などの篇しい 問題を抱え、その生活環境の維持に苦虑している一方、都市住民の ライフスタイルは多様化し、ゆとりある住環境に対するニーズが定 着化している。しかし、都市と農村の関係を包括的に捉える計画的 視点がないため、これらの現状に対して効果的な対応がとれないの が現状である。このような中で平成10年に「優良田園住宅の建設の 促進に関する法律（以下、優良田園住宅促進法）」が施行され、さ らに農村などの都市市街地以外の地域に住宅地を形成するケースが 増加することが予想される。

また、平成12年度の都市計画法の改正も都市計画として保全す心゙ き自然や緑地環境について都市計画区域外も含め積極的に位直付け ていくことが大きな柱の1つであった。今後、都市計画にも農村な どの周辺の環境を計画的に扱うための視点が重要となってくる。

特に北海道の地方都市では、都市は連担性が少なく単独で市街地 が形成され、その郊外部には農地あるいは自然が大きく広がってい ることが多く、農村地域における望ましい住環境イメージの形成と ともに都市の実態に合わせた制度の運用が重要となっている。

\section{2. 本報の目的と方法}

優良田園住宅促進法は農山村地域、都市の近郊等における優良な
二151-8570 東京都渋谷区千䭾 ヶ谷4-25-2)

2 北海道大学大学院工学研究科都市環境工学専攻 博士課程. 工修

*3 北海道大学大学院工学研究科都市環境工学専攻 助教授・工博

U.C. バークレイ校 客員研究員

*4 北海道大学大学院工学研究科都市環境工学専攻 教授. 工博
住宅の建設を促進するための措置を講ずる制度であるが、地方都市 郊外部の土地利用動向に関しては、未線引き自治体における市街化 の実態を農用地区域の指定状況等との関連から明らかにした研究（ 中出ら $\left.2000^{1)}\right)$ 、市街化調整区域の土地利用方針や調整区域内地区 計画、集落地区計画についての研究（川上、木谷1998 ${ }^{2)}$ ) などがあ るが、優良田園住宅促進法の自治体の運用実態についての研究はな い。そこで本報は北海道内における優良田園住宅促進法の活用事例 の把握により、その活用方策について明らかにすることを目的とし、 以下の方法で研究を進める。

(1)北海道内の優良田園住宅促進法の活用の事例をヒアリング調查に より把握し、郊外部の課題、コントロールの手法とその視点、及 び対象地域における住環境イメージについて分析する。

(2)土地利用などの郊外部の課題への対応もふくめ、優良田園住宅促 進法の活用方策について整理する。

なお、本報の郊外部とは、都市計画区域を持つ自治体においては 市街化区域及び用途地域が指定されている区域の外側、また、都市 計画区域を持たない自治体においては既存市街地外の郊外地域であ り、都市的開発の想定される土地の区域を指す。

\section{3. 良田国住宅促進法の活用事例}

ここでは活用自治体に対するヒアリング調査により、郊外部の課 題やコントロールの手法と視点、地域の住環境イメージを把握する。 対象自治体は平成13年1月時点で優良田園住宅促進法の基本方針を 策定済み及びほぼ原案を策定した旭川市、帯広市、由仁町、東川町、 ニセコ町とした蛙1)。旭川市と帯広市は地方中核都市であり都市計画

*1 Fujita Corp., M. Eng.

*2 Graduate student, Hokkaido Univ., M. Eng.

*3 Assoc. Prof., Graduate School of Engineering, Hokkaido Univ., Dr. Eng. Visiting Scholar, City and Regional Planning of U.C. Berkeley

*4 Prof., Graduate School of Engineering, Hokkaido Univ., Dr. Eng. 


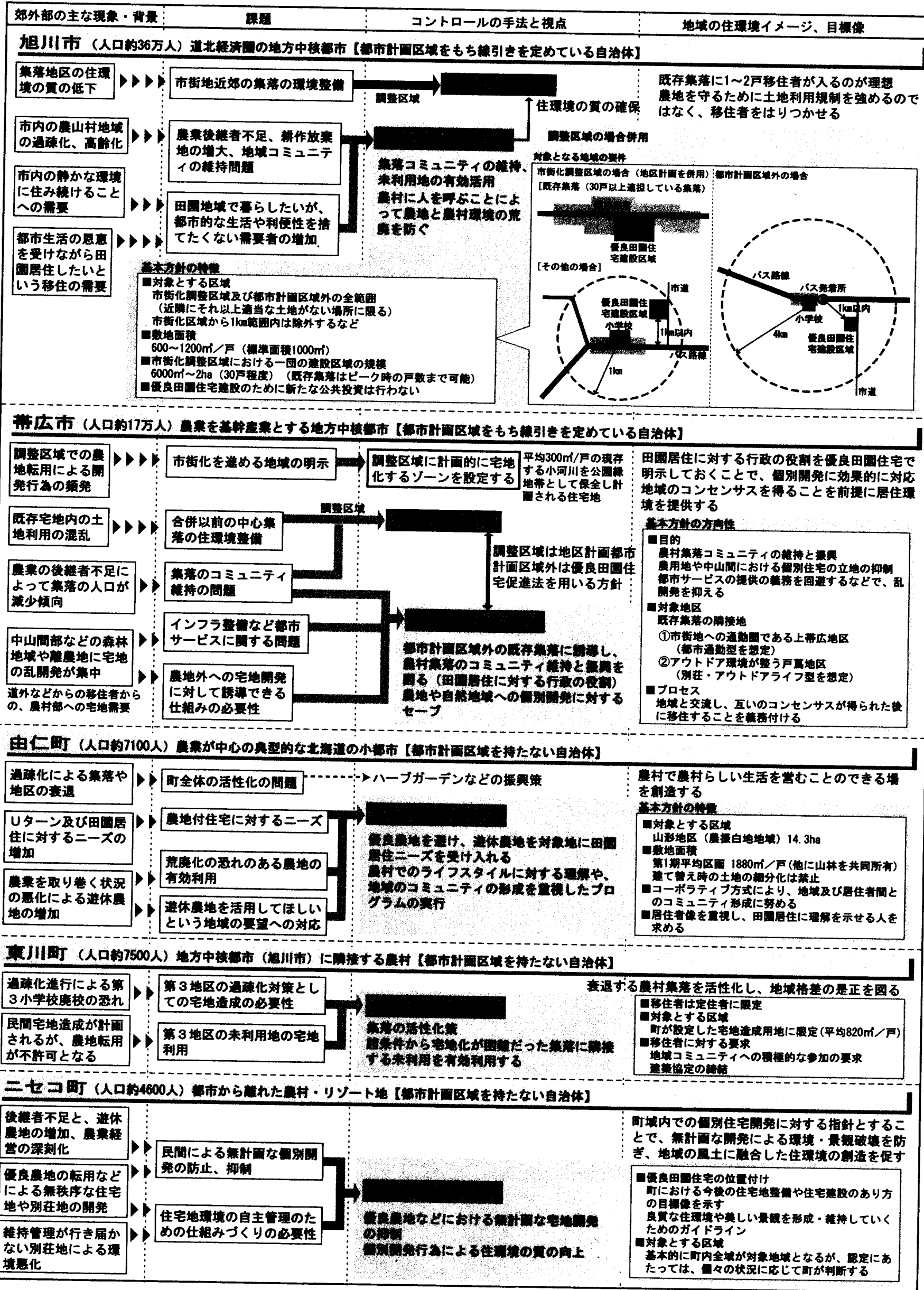

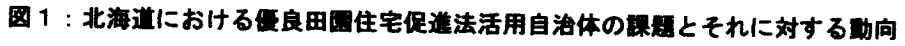


区域を持ちかつ線引きを行っている。一方、由仁町、東川町、二セ コ町は都市計画区域を持たない自治体である。以下にそれぞれの自 治体の活用の視点を整理する（図 1）。

3-1旭川市

郊外部への開発圧力が比較的弱く、市街地の成熟が当面の課題で ある。田園居住に対するニーズと、地域住民の集落機能の維持と離 農に対する意向に対応するため優良田園住宅促進法の活用が決定さ れた。対象地域は基本的に市街化調整区域及び都市計画区域外全域 であるが、優良田園住宅の建設によるスプロール現象の発生など郊 外部の土地利用に新たな問題を生じないよう、敷地規模を $600 \mathrm{~m}^{2}$ 〜 $1200 \mathrm{~m}^{2}$ （標準面積 $1000 \mathrm{~m}^{2}$ ）、さらに市街化調整区域においては一団 の建設区域の規模を $6000 \mathrm{~m}^{2} \sim 2 \mathrm{ha}$ と独自の基準を設けている。
3-2帯広市

市街地は都市計画公園である「帯広の森」に取り囲まれ、コンパ クトに形成されており、その外側は大規模農業地帯が広がる。帯広 市では市街化調整区域の住環境は地区計画で補う方針で、優良田園 住宅は都市計画区域外の農村集落機能の維持のために活用する方針 である。優良田園基本方針を郊外における住宅建設行為に対する行 政の指針として位置付けることで、集落以外の中山間地域などへの 個別住宅建設に対する抑制も意図している。平成13年度中に基本方 針を公表する予定である。

3-3由仁町

同町出身者からのUターンニーズを背景に、ゆとりある田園居住 の実現方法を模索していたところ、優良田園住宅促進法が施行とな

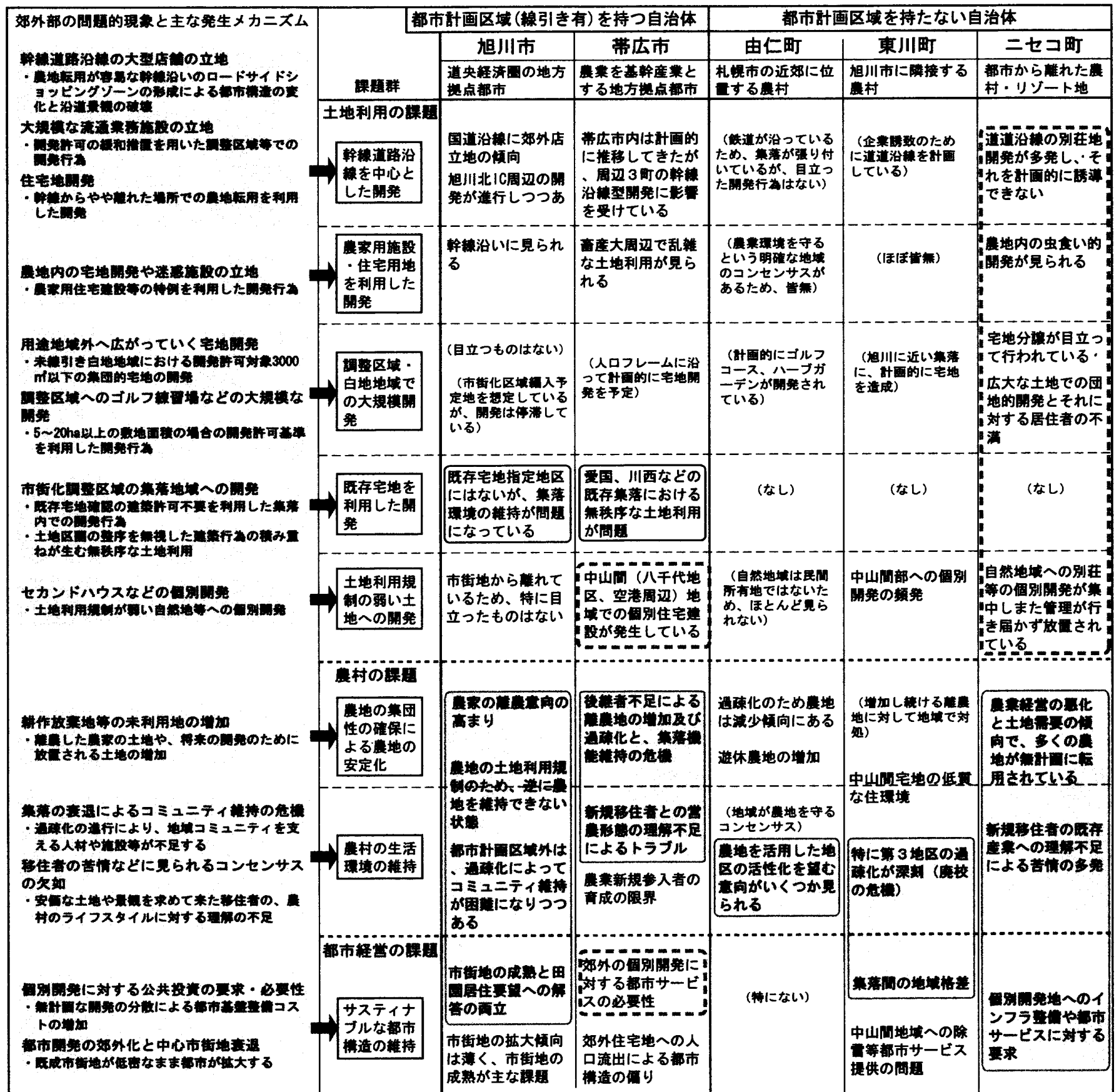

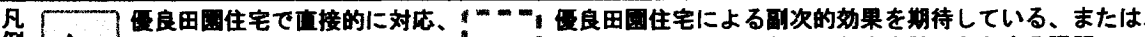
规定している磷百

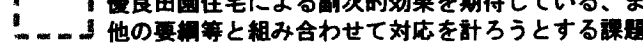

故整区域の地区計画で 扱う予定の的量

图 2 : 郊外部の課居に対する事例自治体のアプローチ 
り、活用を決定した。田園地域の環境を維持するために、移住者に 対して田園にふさわしい居住スタイルを要求している。そのために 移住希望者同士が町の仲介によって面識をつくり、地域運営に関わ っていくシステムを採用するなど、居住者の啓蒙を進めている。 3-4東川町

計画対象地である農村集落地区は隣接する旭川市からもっとも離 れた集落で、新規の住宅建設はほとんどなく過㻋化が急速に進み、 コミュニティ維持の問題が深刻化していた。そこで、優良田園住宅 促進法を活用することで集落に筷接する農地を宅地に転用した。集 落へ移住者を誘致することによって、地域コミュニティの活性化を 意図している。 3-5ニセコ町

豊かな自然と農村風景が広がるニセコ町はリソート地として人気 が高く、優良農地内への住宅地開発、別荘等の自然地域への個別開 発行為とその維持管理実態、移住者の生活環境への認識不足が問題 になっている。このような状況に対して住器境の質の維持と住民間 のコンセンサスの獲得を目指し優良田園住宅促進法の活用が決定さ れた。基本方針を町域内における住宅、別花建設の指針としての性 格を持たせるために町全域を対象区域として設定している。

\section{4. 姐良田国住宅促進法の活用方策}

北海道で優良田園住宅促進法を活用している 5 つの自治体は、そ れぞれ都市の規模も郊外部の課題も異なる。そこでそれぞれの自治 体について郊外部の課題とそれに対する優良田園住宅促進法による 活用方策について整理した結果、以下の特徴が見出せた（図2）。 (1) どの自治体の場合も、優良田園住宅による移住者の誘致によっ て農村集落の課題に対応しようとしている。帯広市と由仁町ではさ らに、新規移住者のライフスタイルや既存の地域コミュニティとの 関わり方といった豊かな田園居住を支える事項等も重視されている。 （2）旭川市では、優良田園住宅に対する指針に加え、市街化調整区 域に対し断片的な個別住宅開発を防止するために最低規模を設定す るなど、基本方針を市街化調整区域や都市計画区域外の土地利用方 針として活用している。都市計画区域外の場合でも、中山間地域な どにむやみに開発が起こらないようなルールが設けられている。

(3)旭川市などでは一戸ごとの優良田園住宅の建設のために新たな 公共投資を行わないこととしている。由仕や東川町の住宅地計画 においても最小限の造成のみとするなどインフラコストを低減した 開発を行っている。また、帯広市やニセコ町も優良田園住宅の基本 方針を定めることによって個別的な開発が発生する中山間地域の土 地利用をコントロールを意図している。

以上のように北海道内で優良田園住宅促進法を先駆的に活用して いる自治体は、郊外部の対象地域における優良田園住宅や住宅地と しての指針のみではなく、郊外部の課題に対応させながら全般的な 住環境イメージや方針についての視点を含め、基本方針を策定して いる。

これまでの整理をまとめると道内における優良田園住宅促進法の 活用事例について、その郊外部の課題に対応した活用方策は以下の 四点に整理される。

(1)優良な田園住宅及び田園住宅地についての指針の確立

計画対象地における優良な田園住宅についての方針を規定する。
道内の事例では教地規模が由仁町の $1880 \mathrm{~m}^{2} /$ 戸など、優良田園住宅 の基淮である $300 \mathrm{~m}^{2}$ 以上を越える広い敷地規模が想定されているた め、良好な田園居住を維持管理するための方針が重要である。また、 セカンドハウスなど個別の開発行為等に対応して、対象を住宅地の みでなく個別の住宅を想定している場合が多い。

(2)農地などの農村環境の保全

優良農地の集団的な保全といった農村環境に対する行政の方針を 明確にすることによって、優良田園住宅の建設を認める地域や田園 住宅地の計画対象地を規定する。北海道内の活用事例は農振農用地 区域外を対象地として想定している。

(3)農村コミュニティの維持、活性化

農村集落での小学校の存続などを含め、集落のコミュニティ維持 のために集落内及び集落に隣接する場所に優良田園住宅建設を誘導 し、新たな定住人口を增やす。また、農村のライフスタイルなどに 対する新規移住者の理解を得る仕組みの構築なども行っている。 (4)郊外部全体の土地利用方針の形成

基本方針を郊外部全体の土地利用の方針として検討し、都市的な 土地利用計画と農業の土地利用計画などとの整合性をはかる。特に 旭川市の基本方針は市街化調整区域における土地利用方針としての 役割が与えられ、方針にそぐわない開発行為を抑制し、無計画な開 発による行政の負担の軽減を目指している。

\section{5. まとめ}

道内の地方都市における優良田園住宅促進法の活用事例の分析に より以下のことが明らかとなった。

1) 道内の活用事例は郊外部の農村地城において田園住宅を想定して おり、良好な田園㻴境の形成のためには周囲の農村環境に対する視 点が不可欠である。

2)優良田園住宅促進法の活用に際してはそれぞれの地域における郊 外部の課題に対応し方策が組み立てられている。特に優良な田園住 宅についての方針の他に農村環境の保全、農村コミュニティ、郊外 部全体の土地利用についての方針を含め、市町村固有の課題に対応 させて活用されている。

今後の課題としては、目標像を具体化するプロセスとその推進に 関わる地域のコンセンサスを得る仕組みの構築に向けた検討が必要 である。

最後に、優良田園住宅促進法の活用状況の調査に協力してくださ った各自治体の担当者の方々に、感謝の意を表します。

被注

注1）ヒアリング調查は平成13年1月に行った。この時点で基本方針を策定公 表していた自治体は由仕町、東川町、二セコ町である。旭川市、带広市は北 海道との協議を行い基本方針の原案が策定された状況であった。

青交文获

1) 藤巻重則・中出文平「未線引き地方都市の市街地周辺部における市街地化 の進行と土地利用制御に関する研究 一柏渏市を事例として一」日本都市計画 学会学術研究論文集No. 35 pp. $319 \sim 3242000$

2）木谷弘司・川上光彦「市街化調整区域における土地利用コントロール方針 に関する調查研究 地方中心都市を事例として一」日本都市計画学会学術研 究論文集No. 33 pp. $511 \sim 5161998$

3) 北海道建設部まちづくり推進室 : 北海道の都市計画、2000.8

4）東川町：優良田園住宅の建設の促進に関する基本方針、1999.12

5) 由仁町：传良田團住宅の建設の促進に関する基本方針、2000.2

6)二セコ町 : 優良田園住宅の建設の促進に関する基本方針、2000.7

7)旭川市 : 偡良田園住宅の建設の促進に関する基本方針、2001.4 